\title{
PRICE THE MAIN CONDITION FOR COFFEE EXPORTS AN ANALYSIS WITH GOOD NEWS AND BAD NEWS APPROACHES IN INDONESIA
}

\author{
Khairil Anwar', Mariyudi ${ }^{2}$ \\ ${ }^{1}$ Malikussaleh University/ Development Economics \\ ${ }^{2}$ Malikussaleh University/ Management \\ Email: khairilanwar@unimal.ac.id, mariyudi@unimal.ac.id
}

\begin{abstract}
This study aims to analyze the effect of prices and income of the United States of America on 5 superior commodities in Indonesia and see between good news and bad news. The research data uses quarterly data from 2005Q1-2017Q4. The research model uses the TGARCH model. The results show that the income per capita of the United States, the previous price per commodity and previous exports have a positive and significant influence on commodity exports. However, the effect of per capita income on superior rubber commodities was found to have a negative and significant effect. This indicates an increase in foreign income will reduce rubber exports. Extreme volatility shocks occur in palm oil and other agriculture. High volatility is only cocoa commodity. Meanwhile, for coffee and rubber, the volatility is low. 3 commodities that have symmetrical information are coffee, cocoa, and other agriculture. Asymmetric information on palm oil and rubber commodities.
\end{abstract}

Keywords: Exports, TGARCH, Volatility, Asymmetry, GDP per Capita

\section{INTRODUCTION}

Export is one of the most appropriate ways to increase the economy. Export activities run if domestic production exceeds domestic demand or excess demand. Generally, developing countries such as Indonesia export raw materials from the agricultural sector more primarily than developed countries which export finished goods that incorporate elements of technology so that the value of goods is higher. In 2009, developing countries almost 35 percent of total exports came from the primary sector (UNCTAD, 2009). Exporting activities of raw goods are not always immediately accepted by importing countries because these goods must also have good quality and compete with other developing countries such as developing countries such as Nigeria, Pakistan, and South Africa. Due to global competition in exporting countries, countries must carry out more specific specifications in order to minimize risks and be accepted by the commodity in the world. (Esteves \& Prades, 2018).

Figure 1.1 illustrates some of the leading commodities that Indonesia exports. Exports of this superior commodity go to developed countries such as the United States,

International Journal of Economic, Business, Accounting, Agriculture Management and Sharia Administration |IJEBAS E-ISSN: 2808-4713 | https://radjapublika.com/index.php/IJEBAS 
Price The Main Condition For Coffee Exports An Analysis With Good News And Bad News Approaches In Indonesia

China, Malaysia, Singapore, to the European region. The types of commodities exported are palm oil (Crude Palm Oil), rubber (Rubber), coffee (Coffee), cocoa (Cacao), and other agriculture (Other Agr. The development of export volume of each commodity explains that palm oil is superior compared to the other 4 commodities. oservations from the beginning of 2005Q1, Indonesia has exported more than 500 tons of palm oil. This palm oil export activity fluctuates sharply. Nevertheless, there was a positive trend until the end of 2017Q4 where exports almost reached 2500 tons or 5 times increase in the last 13 years. In contrast to the other 4 commodities, exports of these commodities are seen below 500 tons. Commodity development did not fluctuate and was even stable until the end of 2017Q4. Among these 4 commodities, cocoa is exported more than coffee and rubber.

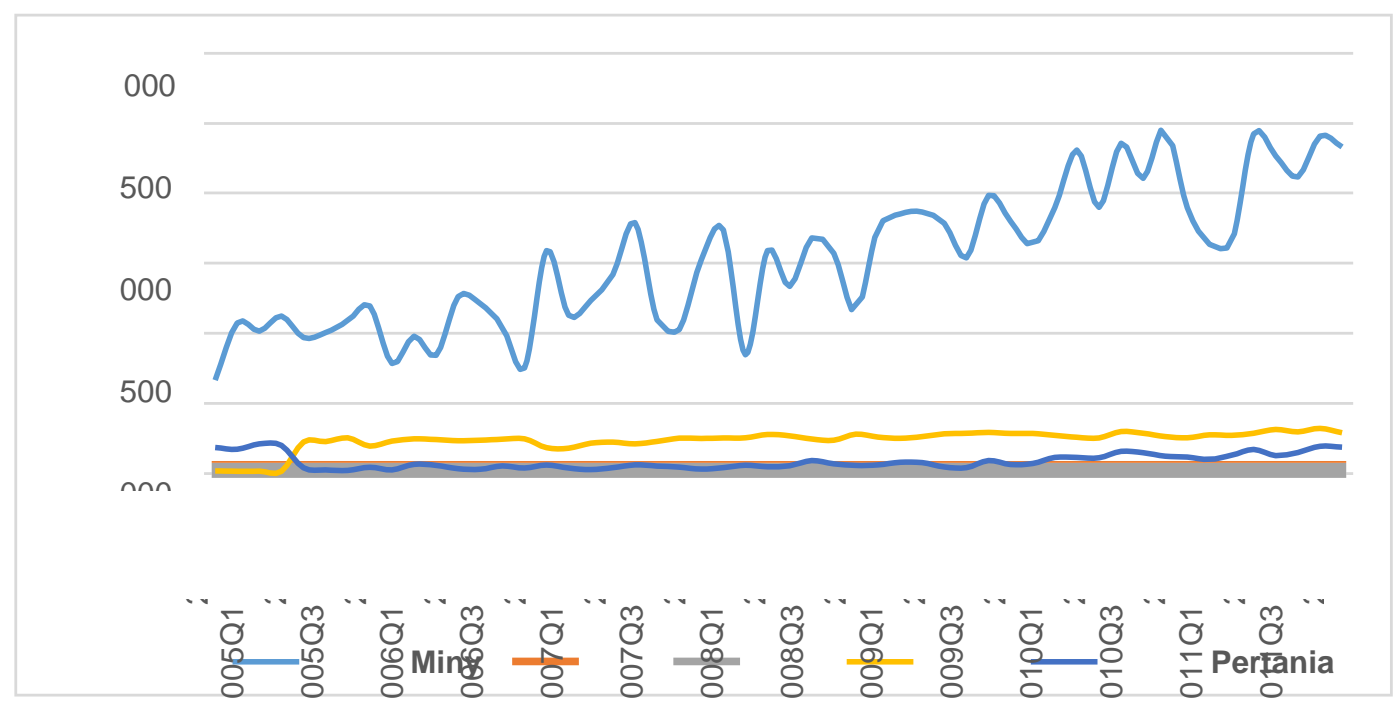

Figure 1.1 Leading Export Commodities in Indonesia Source: Indonesian Economic and Financial Statistics, 2018 (processed) 


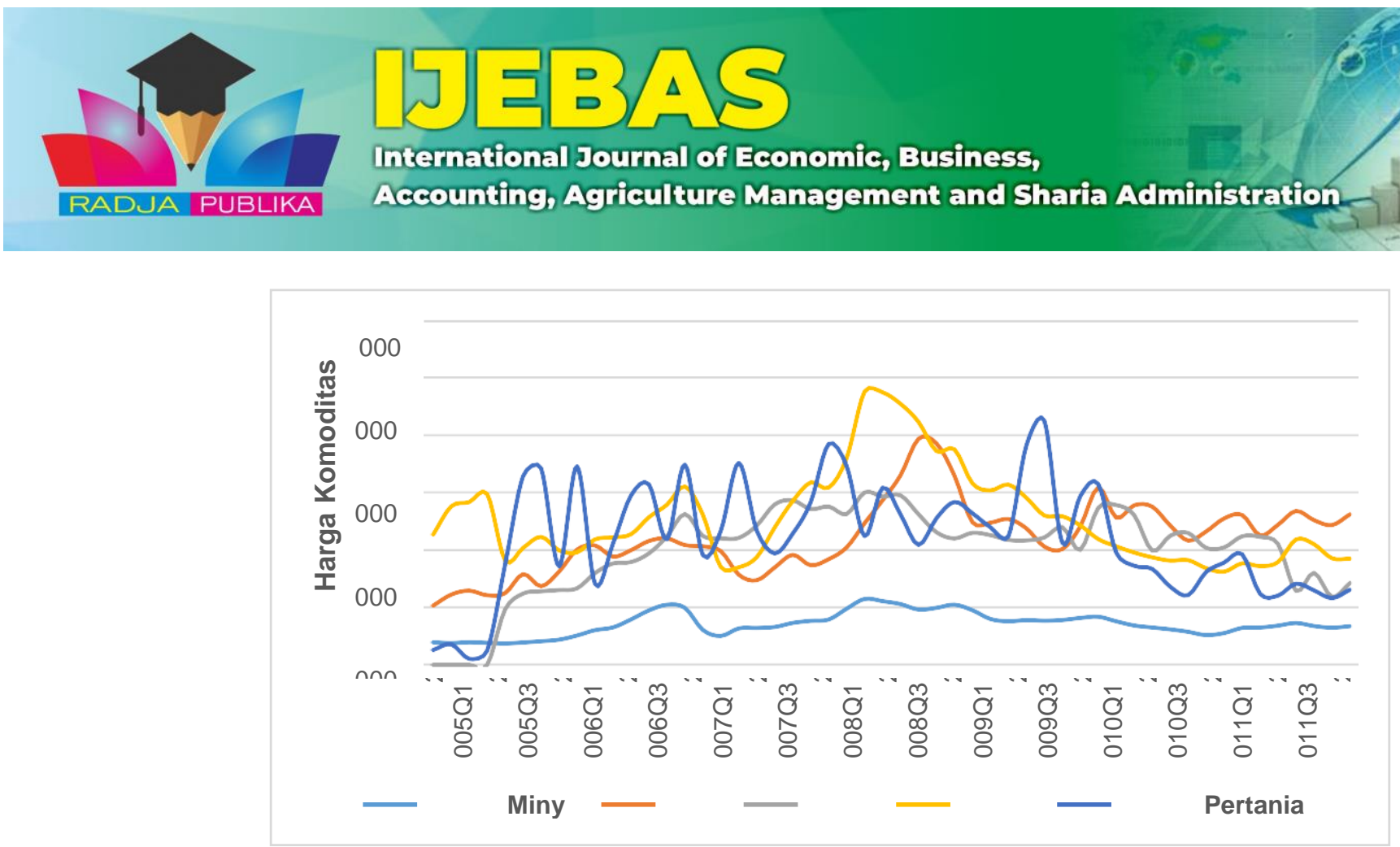

Gambar 1.2 Harga Komoditas Ekspor di Dunia

Sumber: Statistik Ekonomi dan Keuangan Indonesia, 2018 (diolah)

In addition to the excess domestic production, the factor of world commodity prices is an important key in the export sector (Ebadi \& Ebadi, 2015). Similarly, the theory of demand and supply that commodity exports are very sensitive to the influence of the price of the goods themselves (Areerat et al, 2014). The increasing demand from importing countries encourages exporting countries to export more often than meeting domestic needs (Morrisey, 2008; Medina \& Soto, 2016). The development of each commodity price fluctuates significantly both locally and globally depending on market conditions (Jack et al, 2009).

In Indonesia, the comparison between commodity volumes and commodity prices shows that there is a considerable difference. Figure 1.1 explains that the price development of palm oil commodities is not as good as that of coffee, cocoa, and rubber as well as other agricultural commodities. The average price per tonne of palm oil is USD 705.51 per tonne. In the middle of 2008, the price of palm oil increased to 1041 USD per tonne and from 2011 to 2012 there was also an increase between 1047-1104 USD per ton. However, the bad news was seen in 2017Q1 the price of palm oil fell to the level of 669.36 USD per tonne. While the good news emerged from the price of cocoa is better in the world market. This can be seen in 2011Q1-2011Q2 the price of cocoa rose sharply, namely 4747.58 USD per ton. Likewise for coffee prices approaching 4000 USD per tonne, rubber at 3000 USD per tonne.

The income factor of the destination country also influences the increase in a country's exports. On the other hand, dependence on the economy of the importing country is an external factor for the exporting country (Afzal, 2006). One of them is if there is an 
economic recession or the importing country experiences a severe crisis. This influence causes a decrease in demand both domestically and abroad (Pop et al, 2013; Rahmadi, 2012). The long-term effect of this problem leads to sluggish exports to other countries (Kumar, 2011). From the background of this research, it is necessary to conduct an empirical study even though the data can be explained that changes in Indonesia's commodity exports depend on price factors and foreign country income.

\section{LITERATUR REVIEW}

There are some who study exports and volatility, such as Di Giovanni \& Levchenko (2009), using a multiple regression model with 3 model stages, namely Volatility, Correlation, and Specialization at the level of the manufacturing industry. The results show that international trade openness causes the industry to grow rapidly rather than only meeting local needs. The effect of international trade is that the output of commodities for export continues to grow. However, this addition has had a significant impact on commodity prices. This is coupled with industrial specialization which causes higher commodity prices with low production costs.

Furthermore, Ebadi \& Ebad (2015) explain that the volume of exports depends on the macroeconomic conditions of developed countries. The research method uses multiple linear models with dummy variables. The results show that exchange rate volatility, inflation, and previous competitive competition have a positive and significant effect on export volume.

However, the dummy effect of war is positive but not significant. The impact of war makes a country lose resources so that the country that loses the war will import resources from other countries.

Research on exports was investigated by Afzal (2006) in the Pakistan region. The research method uses Granger Causality for the variables of primary and manufacturing exports, world income, and economic growth (GDP). The results show that manufacturing exports and GDP have a very significant two-way relationship. The relationship between primary exports and GDP is only found in one direction, namely primary exports have an effect on GDP. World income and primary and manufacturing exports were not found to have a Granger causality relationship.

Meanwhile, Ahmed \& Sallam (2018) found that the volatility of exports in the agricultural sector in the long term has a positive and significant contribution to GDP.

The study of international trade and the size of the country's economy studied by Karras (2006) found that the implementation of international trade will have a negative and significant effect on the domestic macroeconomy. The impact of international trade causes output, consumption, investment, and exchange rates to weaken. The exchange rate variable with the strongest decline and this weakness also has an impact on the size of the economy and the size of the economy. The results of the latest research by Joets \& 
Razafindrable (2017) with the Threshold Vector Autoregressive (TVAR) model explain this effect not only on macro variables but also on commodity prices.

Research on export commodities in Indonesia, namely Hatane (2011) examines the volatility of export commodities of palm oil, natural rubber, arabica coffee, robusta coffee, cocoa, white pepper, and black pepper in Indonesia. The method used is GARCH with the independent variable, namely the residual from the ARMA average estimate. The results show that high volatility indicates that the commodity under study has a high risk. Rahayu (2015) uses the same model as coffee exports through a price approach. The results explain that the volatility of coffee export commodities is very extreme (extreme volatility). The effect of the prices of the previous first and second years has a positive and significant impact. Meanwhile, Safuan (2017) using the Seemingly Unrelated Regression (SUR) method explains that the demand for export commodity volumes to partner countries (United States, Japan, China) will decrease significantly if there is a depreciation of the rupiah exchange rate and changes in world commodity prices.

\section{METHOD}

To analyze the movement of export commodities in Indonesia, which are influenced by commodity prices and United States income, this study uses a non-linear analysis method, namely maximum likelihood (ML) with the AutoRegressive Conditional Heteroscedasticity (ARCH), Generalized AutoRegressive Conditional Heteroscedasticity (GARCH) and Threshold models. AutoRegressive Conditional Heteroscedasticity (TGARCH).

ARCH, GARCH and TGARCH models are solutions for estimating data that have non- constant variance. While the multiple linear regression model uses OLS estimation and classical assumptions must be met. The procedure cannot be carried out because one of the OLS assumptions is that the variance must be constant over time in order to obtain a BLUE coefficient. However, if there is a violation, the estimation results are not efficient. So this model is a solution. One of the advantages of the model is that it utilizes heteroscedasticity at the right error and produces a more efficient estimate (Nachrowi and Usman, 2006). The disadvantage for this model is that it has to be repeatedly estimated with different $\mathrm{ARCH}$ and GARCH not depending on the same p,q lag.

The basic equation of the ARCH(1) model uses the residual variance of the independent variable itself. The $\mathrm{ARCH}(1)$ model uses the following equation: $Y_{t}=\alpha+\beta_{1} \mathrm{X}_{t}$ $+u_{t}(3.1)$

$$
\begin{aligned}
& u_{t} \mid \Omega_{t} \sim \operatorname{iid} N(0, h t) \\
& h t=\gamma_{0}+\gamma_{1} u^{2}
\end{aligned}
$$

Equation (3.1) is the average equation and (3.2) is the variation equation. The 
Price The Main Condition For Coffee Exports An Analysis With Good News And Bad News Approaches In Indonesia

DOI: $10.54443 /$ ijebas.v1i2.83

$\mathrm{ARCH}(1)$ model explains that the shock from the previous lag 1 has a large effect on the estimation results. This model assumes that 1 must have a positive sign for positive variance (Asteriou \& Hall, 2011).

Equation (3.1) can be extended to the $\mathrm{ARCH}(\mathrm{q})$ model where the residual variance result is the addition of the lag of the residual results such as $\mathrm{ARCH}(2)$ and $\mathrm{ARCH}(3)$. Similarly to $\mathrm{ARCH}(1)$ that must have a positive sign to get a positive variance. The residual variance equation process is as follows:

$$
\begin{aligned}
& h t=\gamma_{0}+\gamma_{t-1} u^{2}+\gamma_{2} u^{2} \\
& h t=\gamma_{0}+\gamma_{I} u t^{2}+\gamma_{2} u_{t-}^{2}+\gamma_{3} u^{2}
\end{aligned}
$$

The ARCH model can also be developed by adding other independent variables such as multiple regression models. The effect of the addition of independent variables will have a sensitive impact on the dependent variable and variance results. In this case, the researcher uses the ARCH model which is transformed into the narutal logarithm form. The model equation is as follows:

$$
\begin{aligned}
& Y_{t}=\alpha+\beta_{1} \mathrm{X}_{t}+\beta_{2} \mathrm{X} 2_{t}+\beta_{3} \mathrm{Y}_{t-1}+u_{t}(3.5) \\
& E X_{t k}=\alpha+\beta_{2} \mathrm{P}_{t-1 k}+\beta_{2} \mathrm{USGDP}_{t}+\beta_{3} \mathrm{EX}_{t-1 k}+u_{t}
\end{aligned}
$$

Where EXk is each commodity, Pt-1k is the previous year's price of each commodity. Equation (3.6) describes the USGDP variable applied to all commodities. While EXt-1k is the impact of exports from the previous year.

Furthermore, the GARCH $(p, q)$ model is a further development of the $\operatorname{ARCH}(q)$ model. This model explains that the lag variance also contributes to the impact of shocks on the estimation results. The following is the general equation for $\operatorname{GARCH}(1,1)$ :

$$
h t=\gamma_{0}+\delta_{1} h_{t-1}+\gamma_{1} u^{2}
$$

TGARCH is an advanced specification of ARCH and GARCH. In contrast to $\mathrm{ARCH}$ and GARCH where the restrictions of the second model are assumed to be symmetrical. The weakness of the second model is that the greater the shock or volatility of the data the results will be in the same direction. If the volatility is positive then the shock is positive and vice versa if the volatility is negative then the result is a negative shock. TGARCH aims to capture the asymmetry of both positive and negative shocks. So the estimation results can show that the negative results are bad news (bad news) and good news (good news) (Wu, 2011). The conditioned variance equation specification for TGARCH $(1,1)$ in the following equation:

$$
h t=\gamma_{0}+\gamma_{1} u_{t-1}^{2}+\theta u^{2} d+\delta_{1} h_{t-1}(3.8)
$$


Where $\mathrm{dt}$ is the dummy variable. Values 1 if ut $<0$ and 0 for everything else. So good news and bad news have different effects. The good news is known from the impact of the coefficient $1+>0$ (positive), while the bad news is known from $1+<0$ (negative). If $>0$ then it is concluded that there is asymmetry news while $=0$ that there is symmetry news. The TGRACH model can be developed to a higher specification by adding more lag errors before (1, 2, $3 \ldots$ q) (Asteriou \& Hall, 2011).

\section{RESULT AND DISCUSSION}

Descriptive statistics have a description of the description of the observed data. Measurement of this picture is seen from the average value or mean, maximum value, minimum value, standard deviation. The results of descriptive statistics are as follows:

Tabel 3.1

Descriptive Statistical Results of Commodity Export Prices and Volumes

\begin{tabular}{llllll}
\hline Panel A (Ln-Harga) & & Mean & Max. & Min & Std. dev \\
\hline Coffee & (COFP) & 7.66 & 8.28 & 6.93 & 0.29 \\
\hline Panel B (Ln-Expor) & & & & & \\
\hline Coffee & (COFEX & 11.20 & 11.88 & 10.29 & 0.39
\end{tabular}

Sumber: Hasil output, 2018.

Table 3.1 provides an overview of the results of the two variables in panel $\mathrm{A}$ the price and panel B the amount of exports. The results from panel A can be seen that from the 5 commodities studied, the cocoa commodity reached the highest value of 8.47 . Then followed by other agricultural commodities at 8.35 , coffee commodities at 8.28 and rubber at 8.01. Indirectly, the prices of these four commodities are very stable in the world market. This can also be seen from the statistical average (mean) which shows that it is at 7 . In contrast to palm oil, it is explained that the highest price per tonne is at position 7.05 with the lowest being 5.90. Furthermore, for other agricultural commodities, it is seen that there is a better price change every year where the average price is far from the minimum price of 4.64 or close to the maximum price.

Panel B describes descriptive statistics with the export volume approach for each commodity. In contrast to the price condition of the palm oil commodity, it was found that the most exported commodity was 14.38 and the lowest was 12.46. Furthermore, it was also found that the condition of rubber commodities was in accordance with the theory that a good price would lead to exports. This cocoa commodity is in the second position with the highest number of exports of 14.08 and the lowest of 10.36. Meanwhile, the rubber commodity itself does not appear to be much exported. The highest export value was 11.73 and the lowest was 7.68. The average rubber export is 10.30 .

The next stage before entering the estimation of $\operatorname{TGARCH}(1,1)$, requires a model

International Journal of Economic, Business, Accounting, Agriculture Management and Sharia Administration |IJEBAS E-ISSN: 2808-4713 | https://radjapublika.com/index.php/IJEBAS 
Price The Main Condition For Coffee Exports An Analysis With Good News And Bad News Approaches In Indonesia

DOI: $10.54443 /$ ijebas.v1i2.83

diagnosis stage for each commodity studied as the dependent variable. The purpose of checking the TGARCH model is to get good model results. There are 3 model checks in this case: heteroscedasticity (ARCH), autocorrelation (Ljung-Box Q), and normality (Jarque-Berra). Following are the results of the model diagnosis:

Tabel 3.2 Diagnosa Model TGARCH

\begin{tabular}{|l|c|c|c|c|c|}
\hline \multicolumn{1}{|c|}{ Diagnostics } & CPO & COF & CCO & RUB & OA \\
\hline ARCH-LM Test & 0.118 & 0.136 & 0.367 & 4.43 & 0.767 \\
(Prob) & $(0.731)$ & $(0.712)$ & $(0.544)$ & $(0.035)^{*}$ & $(0.381)$ \\
\hline $\begin{array}{c}\text { Ljung-Box Q [24] } \\
\text { (Prob) }\end{array}$ & 26.26 & 62.55 & 17.47 & 26.83 & 49.54 \\
& $(0.341)$ & $(0.000)^{* *}$ & $(0.828)$ & $(0.311)$ & $(0.002)^{* *}$ \\
\hline $\begin{array}{c}\text { Normality Test } \\
\text { (Prob) }\end{array}$ & 3.23 & 2.333 & 0.006 & 1.153 & 0.988 \\
& $(0.198)$ & $(0.311)$ & $(0.996)$ & $(0.561)$ & $(0.61)$ \\
& & & & & \\
\hline
\end{tabular}

Sumber: Ouput EViews (2018). *5\%, **1\%

Table 3.2 explains, first, that the palm oil model in the three tests found this model to be free from violation of assumptions or accept $\mathrm{H} 0$, where the prob value is greater than 0.05. Then for the second model, it is explained that the coffee model has a violation of the assumptions on autocorrelation with a prob value of 0.000 which is less than 0.05 . Meanwhile, heteroscedasticity and normality tests were concluded to accept H0.

Third, the same thing for the cocoa model with the palm oil model, namely that the test results are free from violation of assumptions. Fourth, it was found that there was a violation of the assumption in the form of heteroscedasticity $(0.035<0.05)$. Normality and autocorrelation tests were found to be independent. Finally, the fifth model explains that there is a violation of the same model for other agricultural commodities as coffee, that there is a violation of autocorrelation. The discrepancy between the coffee, rubber and other agricultural models indicates that prices on the world market have a different effect on the Indonesian state to export. In addition, other agricultural prices and coffee are also more responsive than other commodities, such as dependence on previous price conditions. Nevertheless, the five models can be studied even though the model obtained is not good enough.

\subsection{Result Estimasition TGARCH}

The estimation results for each commodity using the TGARCH(1.1) approach are as follows: 


\begin{tabular}{|c|c|c|c|c|c|}
\hline & \multicolumn{5}{|c|}{ Table 3.3. Coffee Commodity TGARCH Estimation Results } \\
\hline & Variable & Coefficient & Std. Error & z-statistik & Prob. \\
\hline & $\mathrm{C}$ & -3.166 & 1.618 & -1.957 & $0.050 * * *$ \\
\hline & COFEX $(-1)$ & 0.299 & 0.171 & 1.747 & $0.081^{*}$ \\
\hline & $\operatorname{COFP}(-1)$ & 0.478 & 0.199 & 2.397 & $0.017 * *$ \\
\hline & GDPCUSD & 0.760 & 0.110 & 6.905 & $0.000 * * *$ \\
\hline & \multicolumn{5}{|c|}{ Variance Equation } \\
\hline & $\gamma 0$ & 0.032 & 0.030 & 1.069 & 0.285 \\
\hline & $\gamma 1$ & -0.307 & 0.237 & -1.292 & 0.196 \\
\hline & $\Theta$ & 1.053 & 0.807 & 1.305 & 0.192 \\
\hline & $\Delta$ & 0.504 & 0.429 & 1.175 & 0.240 \\
\hline & R-squared & 0.523 & AIC & 0.140 & \\
\hline & Adj. R-squared & 0.492 & $\mathrm{SC}$ & 0.443 & \\
\hline & DW-stat & 1.710 & $\mathrm{HC}$ & 0.255 & \\
\hline
\end{tabular}

Sumber: Ouput EViews (2018). *10\%, **5\%, ***1\%

Observations in Table 3.3 show that the price of coffee previously had a positive impact on coffee exports, which was 0.47 percent. The model by including the US GDP per capita variable as an external attractiveness factor shows that it has a positive impact on Indonesia's coffee exports. Likewise with the number of previous exports which had a positive impact of 0.29 percent. Statistically these three variables have a significant (significant) effect. Coefficiently, Indonesia's high coffee exports are due to the impact of US GDP per capita, which is 0.76 percent. This means that if there is an increase in America's per capita income by 1 percent, Indonesia's coffee exports will increase by 0.76 percent.

The results of this estimate are in accordance with research by Rahayu (2015) where the prices of the first year before and the second before have a positive impact. However, the volatility conditions found are not as extreme as by Rahayu (2005) and Hatane (2011). This can be seen from the GARCH(-1) value of 0.504 which is smaller than 1 or it can be concluded that low volatility and insignificant. The variance equation explains the coefficient of 1.053 with prob 0.192 that the information condition is symmetrical and $0.654(\gamma 1+)$ is good news.

Furthermore, the estimation results of palm oil in Table 4.5 found different results with coffee commodities. The US GDP per capita coefficient is higher than the other variables, namely

3.44 and significant. If America's per capita income increases by 1 percent, then palm oil exports will increase by 3.44 percent. The impact is up to 3 times. Then the price 
Price The Main Condition For Coffee Exports An Analysis With Good News And Bad News Approaches In Indonesia

DOI: 10.54443/ijebas.v1i2.83

coefficient before and previous exports were positive and significant at the 1 percent level. From the results of the price coefficient proved to have an important role. The better commodity prices in the world, the export activities of palm oil as a superior commodity will continue. On the other hand, if world market prices do not improve, exports will decline.

The explanation of the variance equation that there is high volatility for palm oil commodity with a coefficient of GARCH(-1) is 1.026 and significant. Then, the threshold results give a signal that palm oil is an asymmetry signal and has good news.

Tabel 3.4.

Palm Oil Commodity TGARCH Estimation Results

\begin{tabular}{llcll}
\hline Variable & Coefficient & Std. Error & z-Statistik & Prob. \\
\hline C & -27.228 & 0.215 & -126.713 & $0.000^{* * *}$ \\
CPOEX(-1) & 0.174 & 0.002 & 112.351 & $0.000^{* * *}$ \\
CPOP(-1) & 0.828 & 0.001 & 919.866 & $0.000^{* * *}$ \\
GDPCUSD & 3.446 & 0.022 & 157.756 & $0.000^{* * *}$ \\
\hline Variance Equation & & & \\
\hline$\gamma 0$ & 0.001 & 0.001 & 0.666 & 0.505 \\
$\gamma 1$ & -0.239 & 0.184 & -1.301 & 0.193 \\
$\Theta$ & 0.488 & 0.262 & 1.863 & $0.062^{*}$ \\
$\Delta$ & 1.026 & 0.200 & 5.128 & $0.000^{* * *}$ \\
\hline R-squared & 0.838 & AIC & -0.467 & \\
Adj. R-squared & 0.828 & SC & -0.164 & \\
DW-stat & 2.003 & HC & -0.351 & \\
\hline
\end{tabular}

Source: Ouput EViews (2018). *10\%, **5\%, ***1\%

Table 3.4 explains that the information for this cocoa commodity is found to be symmetrical and has good news. This means that the demand for goods and prices in the world market is very good so that they are feasible for export. One of the main causes of the increase in the export of superior cocoa was the previous export of cocoa with an estimated result of 0.769 . The influence of previous cocoa exports was quite strong compared to previous prices and US per capita income. Statistically the three variables have a significant effect with a significance of 10 percent and 1 percent. The shocks obtained for cocoa commodities are close to high volatility (0.973) and significant (0.000). 


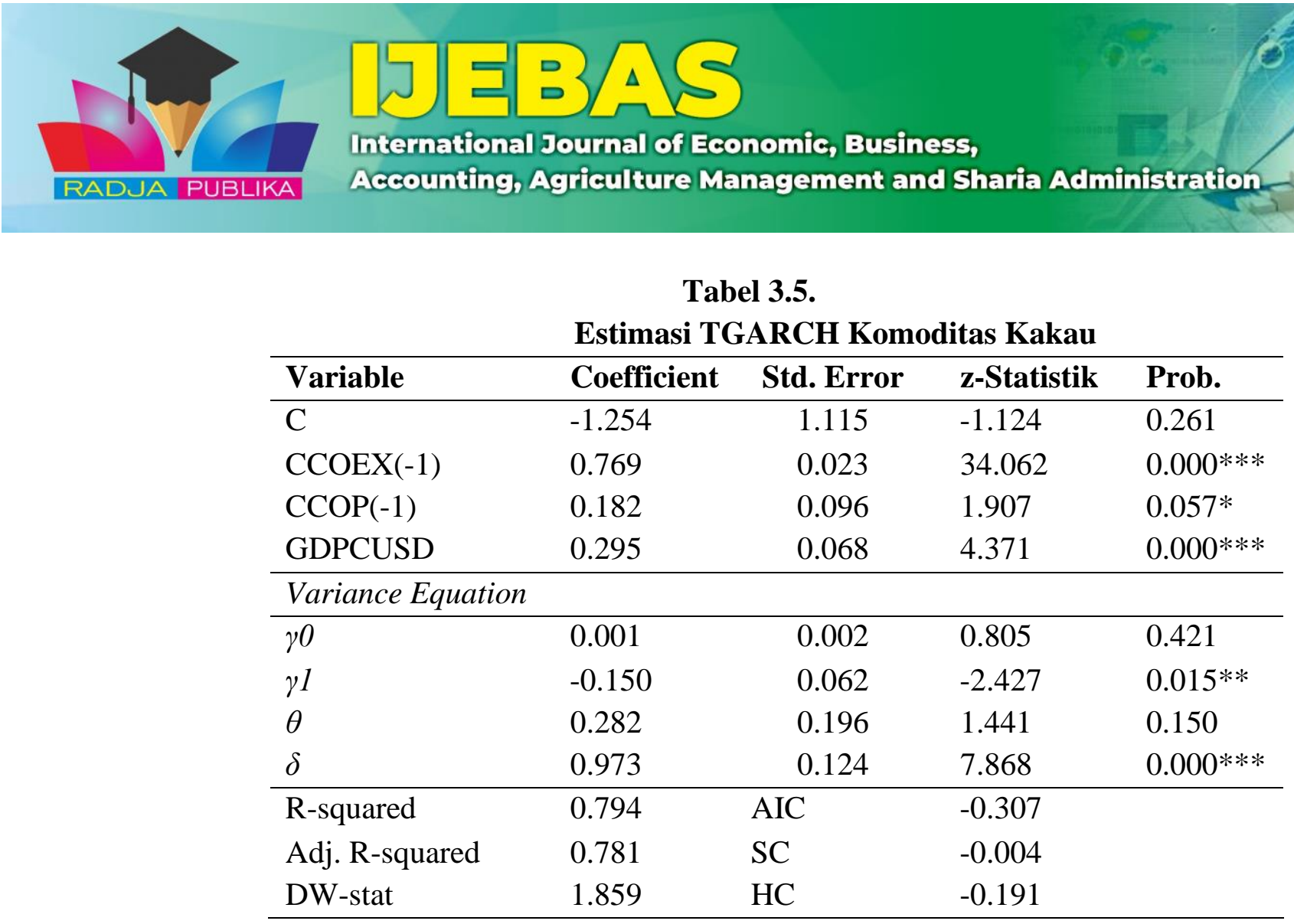

Sumber: Ouput EViews (2018). *10\%, **5\%,***1\%

Rubber is a superior and important commodity that Indonesia exports to other countries. The estimation results of the TGARCH approach in Table 4.7 find that income per capita is negative and significant for rubber exports. The results are very different from othercommodities and contrary to export theory.

This commodity reflects the demand from outside countries does not occur. In fact, the coefficient value has a significant (significant) decrease in the rubber commodity if there is an increase in per capita income of 1 percent with the assumption of cateris paribus. From the previous price approach, it did not have a strong enough impact, namely 0.08 percent and was significant. Symmetry or asymmetry information for superior rubber commodities, found significant asymmetry results with conditions for rubber exports being bad news and significant.

Tabel 3.6

Estimasi TGARCH Komoditas Karet

\begin{tabular}{llcll}
\hline Variable & Coefficient & Std. Error & z-Statistik & Prob. \\
\hline C & 45.476 & 6.851 & 6.638 & $0.000^{* * *}$ \\
RUBEX(-1) & 0.539 & 0.046 & 11.790 & $0.000^{* * *}$ \\
RUBP(-1) & 0.085 & 0.038 & 2.261 & $0.024^{* *}$ \\
GDPUSD & -4.273 & 0.701 & -6.099 & $0.000^{* * *}$ \\
\hline Variance Equation & & & & \\
\hline$\gamma 0$ & 0.053 & 0.069 & 0.765 & 0.444 \\
$\gamma 1$ & -0.239 & 0.070 & -3.402 & $0.001^{* * *}$ \\
$\Theta$ & 0.200 & 0.061 & 3.313 & $0.001^{* * *}$
\end{tabular}

International Journal of Economic, Business, Accounting, Agriculture Management and Sharia Administration |IJEBAS E-ISSN: 2808-4713 | https://radjapublika.com/index.php/IJEBAS 
Price The Main Condition For Coffee Exports An Analysis With Good News And Bad News Approaches In Indonesia

DOI: $10.54443 /$ ijebas.v1i2.83

\begin{tabular}{|c|c|c|c|c|}
\hline$\Delta$ & 0.618 & 0.691 & 0.894 & 0.371 \\
\hline R-squared & 0.883 & AIC & 0.866 & \\
\hline Adj. R-squared & 0.875 & $\mathrm{SC}$ & 1.169 & \\
\hline DW-stat & 2.180 & $\mathrm{HC}$ & 0.981 & \\
\hline
\end{tabular}

Sumber: Ouput EViews (2018). *10\%, **5\%, ***1\%

Tabel 3.7

Estimasi TGARCH Komoditas Pertanian Lainnya

\begin{tabular}{llcll}
\hline Variable & Coefficient & Std. Error & z-Statistik & Prob. \\
\hline C & -25.339 & 0.482 & -52.597 & $0.000^{* * *}$ \\
OAEX(-1) & 0.437 & 0.000 & 1242.448 & $0.000^{* * *}$ \\
OAP(-1) & 0.116 & 0.005 & 24.265 & $0.000^{* * *}$ \\
GDPCUSD & 3.228 & 0.048 & 67.617 & $0.000^{* * *}$ \\
\hline Variance Equation & \multicolumn{5}{|l}{} \\
\hline$\gamma 0$ & 0.001 & 0.001 & 1.558 & 0.119 \\
$\gamma 1$ & -0.110 & 0.080 & -1.386 & 0.166 \\
$\Theta$ & -0.091 & 0.098 & -0.935 & 0.350 \\
$\Delta$ & 1.047 & 0.043 & 24.620 & $0.000^{* * *}$ \\
\hline R-squared & 0.793 & AIC & -0.951 & \\
Adj. R-squared & 0.779 & SC & -0.648 & \\
DW-stat & 2.370 & HC & -0.835 & \\
\hline
\end{tabular}

Sumber: Ouput EViews (2018). *10\%, **5\%,***1\%TGARCH estimation results

Table 4.8 shows the same form as the coffee commodity estimation results. However, the role of the US per capita income coefficient is very strong compared to the coffee and cocoa commodity coefficients but is the same as for commodities. If there is an increase in US per capita income by 1 percent, the export of other superior agriculturalexport commodities will increase by 3.22 percent with the assumption of cateris paribus and this effect is significant at a level of 1 percent. For the coefficient of prices and exports previously obtained a positive and significant effect on other agricultural exports. Where the previous price increase was 1 percent, other agricultural exports were 0.116 percent. Likewise with the previous increase in exports that occurred 0.47 percent if there was an increase of 1 percent. The information found from these results also explains the symmetry and the news obtained is bad news (negative) even though statistically it is not significant. 
Tabel 3.8

Conclusion Estimates per Superior Commodity

\begin{tabular}{|c|c|c|c|c|c|}
\hline Equation & CPO & $\mathrm{COF}$ & $\mathrm{CCO}$ & RUB & $\mathbf{O A}$ \\
\hline $\mathrm{C}$ & - & - & - & + & - \\
\hline $\begin{array}{l}\text { Harga } \\
\text { Sebelumnya } \\
(\mathrm{Pt}-1)\end{array}$ & + & + & + & + & + \\
\hline $\begin{array}{l}\text { Ekspor } \\
\text { Sebelumnya } \\
(\text { Ext-1) }\end{array}$ & + & + & + & + & + \\
\hline $\begin{array}{l}\text { Pendapatan } \\
\text { Negara Luar } \\
\text { (GDPCUSD) }\end{array}$ & + & + & + & - & + \\
\hline $\begin{array}{l}\text { Volatilitas } \\
\text { (GARCH) }\end{array}$ & Extreme & Low & High & Low & Extreme \\
\hline $\begin{array}{l}\text { Asimetri / } \\
\text { Simetri }\end{array}$ & Asimetri & Simetri & Simetri & Asimetri & Simetri \\
\hline $\begin{array}{l}\text { Good news / } \\
\text { Bad news }\end{array}$ & Good news & Good news & Good news & Bad news & Bad news \\
\hline
\end{tabular}

Note: low $<1$, high $=1$, dan extreme $>1$.

Based on the overall estimation results for each commodity, it can be concluded that all variables have a positive and significant influence in increasing the superior exports of the agricultural and plantation sectors. However, the rubber sector is not the same because of the negative and significant impact that reduces demand in exporting. This result is explained by Ebadi \& Ebad (2015) and Safuan (2017) that a country's exports depend on the economy of the destination country. So the demand will continue to increase for certain commodities. The influence of Indonesian exports shows that the United States will import from Indonesia in the form of palm oil, coffee, cocoa, and other agricultural commodities. The most important needs of this country are palm oil and other agriculture because their coefficients are 3.44 and 3.22. In terms of prices and exports previously in accordance with the approach of Rahayu (2015).

The conclusion drawn from this research is that not all export commodities provide good information for Indonesia in the international trade sector. It is known from Table 4.9 , the information captured on palm oil and rubber commodities is not symmetrical. It is very likely that the information discrepancy is caused by changes in commodity standards in trading abroad such as size, quality and type (Karras, 2006). Then in the case of rubber commodities, Indonesia should reduce its rubber export trade abroad because the value of goods made from raw materials is lower and processing of goods into semi-finished and 
Price The Main Condition For Coffee Exports An Analysis With Good News And Bad News Approaches In Indonesia

DOI: $10.54443 /$ ijebas.v1i2.83

finished products is required so that the added value is high. It differs from coffee and cocoa commodities in that the information is simian and good news is obtained, so the recommendation is that Indonesia continues to increase the export volume of both as superior commodities.

\section{CONCLUSION}

This study aims to analyze the effect of commodity prices and income of the United States on superior commodities and see the good and bad news of the commodity itself. The conclusion is that the price of each commodity has a positive impact on commodities for export, both in terms of today's prices and previous prices. Extreme volatility shocks occurred in oil palm and other agricultural commodities, while coffee and rubber had low volatility. Against 2 commodities of information asymmetry, namely palm oil and rubber. The recommendation from this research is that the government continues to monitor and improve superior commodities such as cocoa, coffee, and other agriculture because information on international prices is symmetrical. Furthermore, the increase in exports is not only for superior commodities, but also for other products.

\section{REFERENCE}

Afzal, M. (2006). Causality between exports, world income and economic growth in Pakistan.

$$
\text { International Economic Journal, } \quad 20(1), \quad 63-77 .
$$

http://doi.org/10.1080/10168730500515399

Ahmed, O., \& Sallam, W. (2018). Studying the volatility effect of agricultural exports on agriculture share of GDP: The case of Egypt, 13(8), 345-352. http://doi.org/10.5897/AJAR2016.11920

Areerat, T., Hiroshi, Kameyama, Ito, \& Shoichi. (2014). Price volatility of grains : relationship with crude oil prices using ccc-garch model. American Journal of Economics and Business Administration, 6(4), 138-142.

Asteriou, D., \& Hall, S. G. (2011). Applied Econometrics. Palgrave Macmillan, 492.

Bustaman, A., \& Jayanthakumaran, K. (2007). the Impact of Exchange Rate Volatility on Indonesia' $\mathrm{S}$ Exports To the Usa: an Application of Ardl Bounds. International Journal of Applied Business and Economic Research, 5(1), 1-21.

Di Giovanni, J., \& Levchenko, A. A. (2009). Trade openness and volatility. Review of Economics and Statistics, 91(3), 558-585. http://doi.org/10.1162/rest.91.3.558

Ebadi, A., \& Ebadi, A. (2015). How the Export Volume Is Affected by Determinant Factors in a Developing Country? Research in World Economy, 6(1), 143-150. http://doi.org/10.5430/rwe.v6n1p143

Esteves, P. S., \& Prades, E. (2018). Does export concentration matter in economic adjustment programs? Evidence from the euro-area. Journal of Policy Modeling, 
40(2), 225-241. https://doi.org/10.1016/j.jpolmod.2017.10.005

Gabriele, A. (2004). Exports of Services and Economic Growth in Developing Countries. Unctad, (June).

FRED. (2018). Gross Domestic Product US. Retrieved from https://fred.stlouisfed.org/series/GDP

Guillaumont, P., \& Combes, J.-L. (2000). Commodity Price Volatility, Vulnerability and Developement. CERDI: Document de Travail de La Série Etudes et Documents, 20(1), 25- 39.

Hachula, M., \& Hoffmann, S. (2014). The Output Effects of Commodity Price Volatility: Evidence from Exporting Countries*. Retrieved from http://www.boeckler.de/pdf/v_2014_10_30_hachula_hoffmann.pdf

Hoffmann, S. (2015). The output effects of comodity price volatility: Evidence from exoporting countries. www.econstor.eu.

Jacks, D. S., Fraser, S., Rourke, K. H. O., Dublin, T. C., Catão, L., Gregory, B., ... Matthews, A. (2009). No Title, (February).

Joëts, M., Mignon, V., \& Razafindrabe, T. (2017). Does the volatility of commodity prices reflect macroeconomic uncertainty? Energy Economics, $\quad 68$, $313-326$. http://doi.org/10.1016/j.eneco.2017.09.017

Karras, G. (2006). Trade Openness, Economic Size, and Macroeconomic Volatility: Theory and Empirical Evidence. Journal of Economic Integration, 21(2), 254-272. http://doi.org/10.2307/23000612

Khin, A. A., Chau, W. H., Yean, U. L., Keong, O. C., \& Bin, R. L. L. (2017). Examining between Exchange Rate Volatility and Natural Rubber Prices: Engle-Granger Causality Test. International Journal of Economics and Financial Issues, 7(6), 33 40.

Kumar, S. (2011). Estimating export demand equations in selected Asian countries. Journal of Chinese Economic and Foreign Trade Studies, 4(1), 5-16. http://doi.org/10.1108/17544401111106770

Medina, J. P., \& Soto, C. (2016). Commodity prices and fiscal policy in a commodity exporting economy. Economic Modelling, 59, 335-351. http://doi.org/10.1016/j.econmod.2016.08.002

Moreira, R. R. (2014). Commodities Prices Volatility, Expected Inflation and GDP Levels: An Application for a Net-exporting Economy. Procedia Economics and Finance, 14(14), 435- 444. http://doi.org/10.1016/S2212-5671(14)00732-1

Morrissey, O., \& Mold, A. (2008). Explaining Africa's Export Performance - Taking a New Look. Economic Journal. 
Price The Main Condition For Coffee Exports An Analysis With Good News And Bad News Approaches In Indonesia

DOI: $10.54443 /$ ijebas.v1i2.83

Pop, L. N., Rovinaru, F., \& Rovinaru, M. (2013). Commodity price volatility during and after the economic crisis-implications for Romania. South East European Journal of Economics and Business, 8(1), 45-52. http://doi.org/10.2478/jeb-2013-0003

Rahayu, M. F., Chang, W.-I., \& Anindita, R. (2015). Volatility Analysis and Volatility Spillover Analysis of Indonesia's Coffee Price Using Arch/Garch, and Egarch Model. Journal of Agricultural Studies, 3(2), 37. http://doi.org/10.5296/jas.v3i2.7185

Rahmaddi, R. (2012). How Do Foreign and Domestic Demand Affect Exports Performance? An Econometric Investigation of Indonesia's Exports. Modern Economy, 03(January), 32-42. http://doi.org/10.4236/me.2012.31005

Rude, J., \& An, H. (2015). Explaining grain and oilseed price volatility: The role of export restrictions. Food Policy, 57, 83-92. http://doi.org/10.1016/j.foodpol.2015.09.002

Saarce Elsye Hatane. (2011). The Predictability of GARCH-Type Models on the Returns Volatility of Primary Indonesian Exported Agricultural Commodities. Jurnal Akuntansi Dan Keuangan, 13(2), 87-97. Retrieved from http://puslit2.petra.ac.id/ejournal/index.php/aku/article/view/18460

Safuan, S. (2017). Exchange Rate Volatility and Export Volume: The Case of Indonesia and its Main Trading Partners, $X X(3), 3-13$.

SEKI. (2018). Statistik Ekonomi dan Keuangan Indonesia. Retrieved from https://www.bi.go.id/en/statistik/seki/terkini/eksternal/Contents/Default.aspx

Shane, M., Roe, T., \& Somwaru, A. (2008). Exchange Rates, Foreign Income, and U.S. agricultural exports. Agricultural and Resource Economics Review, 37(2), 160-175.

South Centre. (2010). Commodity Dependence and International Commodity Prices. South Centre, 56-82. Retrieved from http://www.undp.org/content/dam/undp/library/Poverty Reduction/Inclusive development/Towards

Human

Resilience/Towards_SustainingMDGProgress_Ch2.pdf

UNCTAD. (2012). Excessive commodity price volatility: Macroeconomic effects on growth and policy options. United Nations Conference on Trade and Development, (April), 51. Retrieved from http://unctad.org/en/Docs/gds_mdpb_G20_001_en.pdf

Volpe Martincus, C., \& Carballo, J. (2012). Export promotion activities in developing countries: What kind of trade do they promote? Journal of International Trade and Economic Development, 21(4), 539-578. http://doi.org/10.1080/09638199.2010.500741

Wong, H. T., \& Lee, H. A. (2016). Exchange rate volatility and exports of Malaysian manufactured goods to China: An empirical analysis. International Journal of Business and Society, 17(1), 145-149.

Wu, J. (2011). Threshold GARCH Model: Theory and Application, (October), 1-78. 